\title{
Diagnosis of Short Circuit Faults in Stator Winding of Motor based on Hidden Markov Model
}

\author{
Hisahide Nakamura Member (TOENEC Corporation) \\ Yukio Mizuno Member (Nagoya Institute of Technology) \\ Tatsuya Suzuki Member (Nagoya University)
}

Keywords: fault diagnosis, Hidden Markov Model, motor, turn to turn short circuit fault

This paper proposes a new diagnosis method for turn to turn short circuit faults in stator winding of motor based on Hidden Markov Model. Short circuit fault of a motor is one of the most probable faults. When the fault occurs, the current waveform flowing in the motor is no longer sinusoidal which is observed in a healthy motor. Furthermore, the change of the waveform depends on the position and degree of short circuit fault of the windings. This implies that it is possible to diagnose the fault by paying attention to the pattern of current waveforms. As one on the promising model for analysis and recognition of the time series data, Hidden Markov Model is introduced in this paper. Parameters of Hidden Markov Model are given by three probabilities as follows:

- The transition probability $a_{i j}$ : state transition probability from states $i$ to $j$.

- The output probability $b_{i}(x)$ : occurrence probability of the feature vector $x$ at state $i$.

- The initial state probability $\pi_{i}$

In the training step, parameters must be determined so as to maximize the likelihood of the corresponding training data for each type of fault. In the recognition step, the likelihood of the measured unknown data for each trained model is calculated and compared. Then, the model which shows the highest likelihood can be regarded as the corresponding fault.

The proposed method was applied to the diagnosis of the turn to turn short circuit faults in stator winding of motor. In this paper, some actual induction motors were prepared and 4 types of turn to turn short circuit faults were reproduced artificially in the phase $\mathrm{W}$ of motors. The current waveforms under the healthy situation and under the situation of the 6-turn short circuit fault are shown in Figs. 1 and 2, respectively. As shown in these figures, when the fault occurs, the current waveform is slightly distorted from the sinusoidal. Hidden Markov Model can recognize such a slight difference between waveforms and a highly reliable diagnosis is expected.

To verify the usefulness of the proposed method, other new motors with several turn to turn short circuit faults were prepared

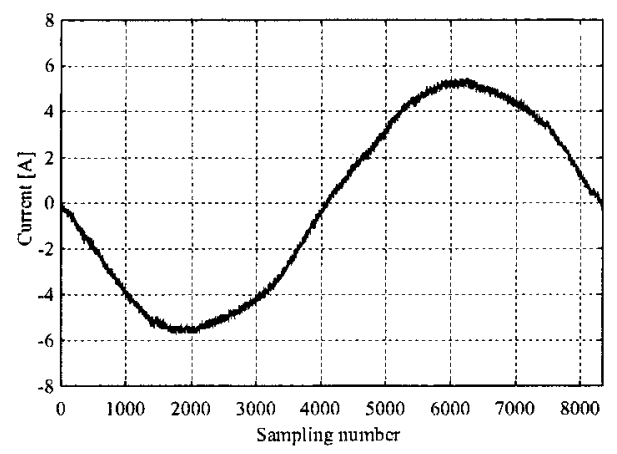

Fig. 1. Current waveform in healthy mode

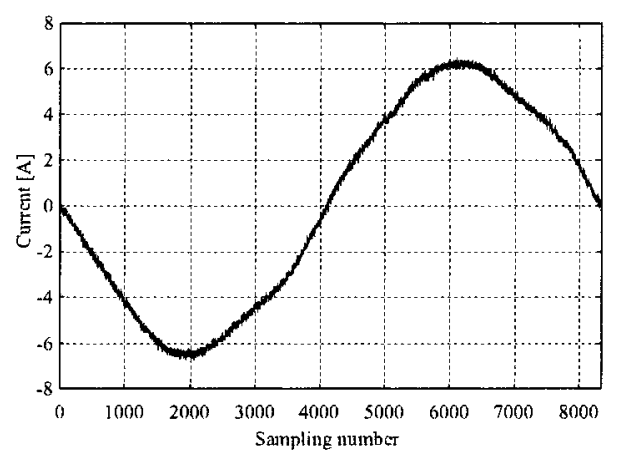

Fig. 2. Current waveform in 6-turn short circuit fault

and current waveforms were measured. Next, several pattern recognitions were carried out between the current waveforms obtained by these new motors and those memorized in a computer as training data in advance. It was proved that current waveform recognition based on Hidden Markov Model was quite effective for diagnosis of several types of turn to turn short circuit faults of stator winding of motor. 


\title{
隠れマルコフモデルに基づいた電動機固定子巻線の短絡診断
}

\author{
正 員 中村 久栄* 正 員 水野 幸男** \\ 正 員 鈴木 達也***
}

\section{Diagnosis of Short Circuit Faults in Stator Winding of Motor \\ based on Hidden Markov Model}

Hisahide Nakamura*, Member, Yukio Mizuno**, Member, Tatsuya Suzuki***, Member

This paper proposes a new diagnosis method for short circuit faults in stator winding of motor based on Hidden Markov Model. Short circuit fault of a motor is one of the most probable faults in motor drive systems. When the fault occurs, the current waveform running in the motor is no longer sinusoidal which is observed in the healthy motor. The variation of the waveform in the faulty case depends on the location and degree of short circuit fault in the winding. In this paper, a Hidden Markov Model (HMM), which is widely used in the field of speech recognition, is exploited to capture and recognize the variation in the faulty current waveform. Thanks to the similarity between the speech signal and the current waveform, the HMM is highly expected to work as a robust fault diagnoser. Finally, the usefulness of the proposed diagnosis method is verified through some experiments using real faulty current waveforms.

キーワード：故障診断，隠れマルコフモデル，電動機，巻線間短絡故障

Keywords: fault diagnosis, Hidden Markov Model, motor, turn to turn short circuit fault

\section{1. はじめに}

産業用電動機は, 幅広い分野での基幹動力源として，プ ラントや工場の製造ラインをはじめとするさまざまな分野 で用いられている重要な技術要素である。このため，工場 内の製造ラインで使用されている電動機においてひとたび 故障が発生すると, 製造ラインは停止となり, 復旧にも長時 間を要することが多く，その結果，多大な損害をもたらし， 経営に与える影響は深刻なものとなる。このことから，電 動機での故障防止の信頼性向上への期待はますます高まっ ており, 安全かつ効率的な運転のための電動機の故障診断 技術に関する研究が欧米を中心に盛んになりつつある (1) (7)。

O.V. Thorsen らは，高圧誘導機を対象とした故障部位の 調査を行っている ${ }^{(8)}$ 。その報告によると，固定子巻線はべ アリングに次いで故障発生割合が高い部位であることが述

\footnotetext{
*(株) トーエネック

T457-0819 名古屋市南区滝春町 1-79

TOENEC Corporation

1-79, Takiharu-cho, Minami-ku, Nagoya 457-0819

** 名古屋工業大学大学院ながれ領域 機能工学専攻

干 466-8555 名古屋市昭和区御器所町

Nagare College, Nagoya Institute of Technology

Gokiso-cho, Showa-ku, Nagoya 466-8555

*** 名古屋大学大学院 工学研究科 機械理工学専攻

于 464-8603 名古屋市千種区不老町

Dept. of Mechanical Science and Engineering, Nagoya University

Furo-cho, Chikusa-ku, Nagoya 464-8603
}

ベられている。このため, 電動機固定子巻線の状態を診断 する技術の確立は, 産業界において切望されている。

電動機の固定子巻線の絶縁劣化は電圧ストレス, 熱スト レス, 機械ストレス, 環境ストレスなどの要因が複合的に作 用することで進展する ${ }^{(9)}$ 。そして劣化が進行すると, 絶縁 破壊, さらには巻線間短絡, 相間短絡, 地絡へ至る ${ }^{(10)}$ 。巻 線間の短絡を診断する手法としては, 三相分の電流の検出 值をもとに, Park ベクトルの形状を故障検出の手がかりと する手法 ${ }^{(11)}$ やエアギャップトルクによる手法 ${ }^{(12)}$ などが提 案されている。一般に, 固定子内で短絡が発生すると, 回 転機はもはや三相平衡ではなくなるため, 電動機へ流れる 電流は正常時のものとは異なる。しかしながら, 固定子巻 線の短絡を診断する手法として, 電流波形そのものの形状 に注目する診断手法はこれまで報告されていない。本論文 では, 固定子巻線において短絡が発生すると, 電流波形が 変形することに注目し，その波形に対して隠れマルコフモ デル（Hidden Markov Model：以下 HMM）を用いること でパターン認識を行い, 巻線状態を診断する手法を新たに 提案する。

HMM は, 訓練集合からモデルのパラメータを推定する 数学的に明確で実現容易な方法があること, モデルの構造 (規模や型) を認識対象に応じて設計できる柔軟性を持って いる等の特徵を備えていることから, 音声認識の分野では 盛んに用いられるようになっている ${ }^{(13)(14)}$

また, 国内外の電源電圧は, 周波数軸 (= 時間軸) 方向と 
振幅軸方向に，わずかではあるが絶えず変動している。こ のため,この電源を電動機駆動用に用いる場合には, 電動機 に流れる電流も電圧変動の影響を受けて変動する。HMM は，時間軸方向と振幅軸方向への変動を統計的にモデル化 するため，さまざまな要因で変動する時系列信号の表現と して適している。

本論文では，はじめに HMM の概要説明を行う。次に, 実際に三相誘導電動機において巻線間短絡を再現させ，そ のときの電流波形の測定結果について述べる。この再現実 験により得られた電流波形に対して, HMMに基づいて波 形パターンの学習を行いパラメータ化し，これらの電流波 形のパラメータをコンピュータに記憶させておく。最後に， 新たに巻線間短絡状態にある三相誘導電動機を準備し，そ こから得られる電流波形と，あらかじめコンピュータに記 憶させておいた波形パターン群との間でパターン認識を行 う。これにより，電動機が短絡状態にあるかどうかの状態 を診断し，本手法の有用性を検証する。

\section{2. 隠れマルコフモデル ${ }^{(15}$}

〈2・1〉 HMM の 3 つの基本問題 HMM は，不確定 な時系列データをモデル化するための有効な統計的手段で ある。HMM の枠組みは統計モデルという点では単純な考 えであり，数学的に取り扱いやすい，信号のゆらぎなどを 確率分布として表現できロバストである，モデルパラメー 夕の学習やモデルに基づいた推論を効率的に行うアルゴリ ズムが存在する等の利点がある。

HMM の概念図を図 1 に示す。HMM は

・初期状態確率 $\pi_{i}$ : 初期状態が状態 $i$ である確率。

- 状態遷移確率 $a_{i j}$ : 状態 $i$ にいるとき, 次の時刻で状態 $j$ に遷移する確率。

- 出力確率 $b_{i}(x)$ : 状態 $i$ で特徵量 $x$ を出力する確率。 をパラメータとして持ち，このパラメータを $\lambda=(\pi, a, b)$ と表現する。

HMM に関して重要な基本問題として次の 3 つがある。

(1) 評価 : 観測系列 $O=\left(o_{1} o_{2} \cdots o_{T}\right)$ とパラメータ $\lambda$ が与えられたとき，パラメータに対する観測系列の 尤度 (もしくは生成確率と呼ばれる $P(O \mid \lambda)$ をいかに 効率よく計算するか。

(2) 状態遷移系列推定 : 観測系列 $O=\left(o_{1} o_{2} \cdots o_{T}\right)$ と パラメータ入が与えられたとき，パラメータ $\lambda$ が観 測系列 $O$ を出力するときの最も可能性の高い状態系 列 $S=\left(s_{1} s_{2} \cdots s_{T}\right)$ をいかに選ぶか。

(3) 学習: 観測系列 $O$ が与えられたとき, $P(O \mid \lambda)$ を最 大にするようにパラメータ $\lambda$ をいかに調整するか。

問題（1）は，与えられたパラメータが，与えられた観 測系列に対してどの程度，適合するかのスコアリング（評 価）の問題である。問題（2）は，モデルの隠れた部分を 明らかにしようとする問題であり，正しい状態系列を求め ることである。問題（3）は，与えられた観測系列がいか に生成されたかを最もよく記述するようにパラメータ $\lambda を$

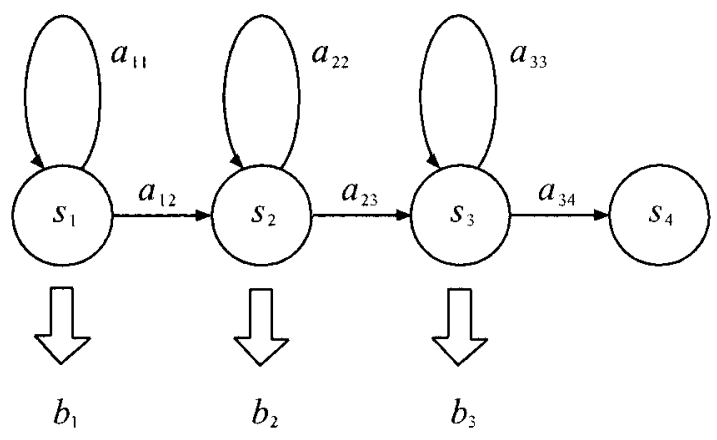

図 1 HMM の構造

Fig. 1. Structure of HMM.

最適化する問題である。

〈2・2〉 評 価 パラメータ $\lambda$ が与えられたときの 観測系列 $O=\left(o_{1} o_{2} \cdots o_{T}\right)$ に対する確率 $P(O \mid \lambda)$ を計算する ことを考える。状態が $S=\left(s_{1} s_{2} \cdots s_{T}\right)$ と遷移して, 観測 系列 $O=\left(o_{1} o_{2} \cdots o_{T}\right)$ が出力される確率は, 遷移確率と各 状態での出力確率を掛け合わせることにより,

$$
P(O, S \mid \lambda)=\prod_{t=1}^{T} a_{s_{t-1} s_{t}} b_{s_{t}}\left(o_{t}\right)
$$

で与えられる。このため, 観測系列 $O=\left[o_{1} o_{2} \cdots o_{T}\right]$ がパ ラメータ $\lambda$ から出力される確率は, すべての可能な状態遷 移の組合せについて和をとることにより，

$$
\begin{aligned}
P(O \mid \lambda) & =\sum_{S} P(O, S \mid \lambda) \\
& =\sum_{S} \prod_{t=1}^{T} a_{s_{t-1} s_{t}} b_{s_{t}}\left(o_{t}\right)
\end{aligned}
$$

と表すことができる。

しかしながら，(2) 式によると，状態数が $N$ 個の場合に は，各時刻 $t$ で到達可能な状態が $N$ 個あることから，可能 な状態遷移系列の総数は $N^{T}$ 個となる。この結果，(2) 式を 解くために $2 T N^{T}$ のオーダの計算が必要となり, 効率的な 方法が必要となる。この効率的な計算方法として，前向き アルゴリズムと呼ばれるアルゴリズムが存在する。

〈2・2・1〉 前向きアルゴリズムパラメータ $\lambda$ が与え られたときに観測系列 $o_{1} o_{2} \cdots o_{t}$ を出力し, 時刻 $t$ で状態 $s_{i}$ に存在する確率 $\alpha_{t}(i)$ を考えると, 各時刻 $t=1, \cdots, T-1$, 各状態 $j=1, \cdots, N$ について, $\alpha_{t}(j)$ を次式のように再帰的 に計算することができる。

$$
\alpha_{t+1}(j)=\left[\sum_{i=1}^{N} \alpha_{t}(i) a_{i j}\right] b_{j}\left(o_{t+1}\right)
$$

この $\alpha$ は前向き確率と呼ばれる。この結果， $P(O \mid \lambda)$ は次の ようになる。

$$
P(O \mid \lambda)=\sum_{i=1}^{N} \alpha_{T}(i)
$$


このアルゴリズムにより，計算量を $N^{2} T$ のオーダに大幅削 減することができる。

〈2·2·2〉 後向きアルゴリズム＼cjkstart前向きアルゴリズム では，時間軸方向に前向き確率 $\alpha$ を計算することにより， $P(O \mid \lambda)$ を求めたが，同様の考えで，時間軸方向とは逆向き に $P(O \mid \lambda)$ を求めることができる。これは後向きアルゴリズ ムと呼ばれている。

いま，後向き確率 $\beta_{t}(i)$ を状態 $s_{i}$ から始まる状態遷移に よって時刻 $t+1$ から終端までの観測系列の確率であるとす ると, 各時刻 $t=T-1, \cdots, 1$, 各状態 $i=1, \cdots, N$ につい て, $\beta_{t}(i)$ は次式のように再帰的に計算することができる。

$$
\beta_{t}(i)=\sum_{j=1}^{N} a_{i j} b_{j}\left(o_{t+1}\right) \beta_{t+1}(j)
$$

$\langle\mathbf{2} \cdot \mathbf{3}\rangle$ 状態遷移系列推定 状態遷移系列の推定とは, 与えられた観測系列 $O=\left(o_{1} O_{2} \cdots o_{T}\right)$ に対する 1 本の最 尤状態系列 $S=\left(s_{1} s_{2} \cdots s_{T}\right)$ を求める問題である。これは Viterbi アルゴリズムと呼ぶ手法により求めることができる。 時刻 $t$ で状態 $s_{i}$ に到達する状態遷移系列のうち, 最大の確 率值を与えるものだけを記憶していけば，最終的に最尤状 態遷移系列を求めることができる。時刻 $t$ で状態 $s_{i}$ に到達 する状態遷移系列に関して最大の確率值を $\delta_{t}(i)$ で表すと, $\delta_{t}(i)$ は (6) 式により再帰的に計算することができる。

$$
\delta_{t+1}(j)=\max _{i}\left[\delta_{t}(i) a_{i j}\right] \cdot b_{j}\left(o_{t+1}\right) .
$$

実際に状態遷移系列をつないでいくためには, 各時刻 $t$, 各 状態 $j$ で(6) 式を最大にする経路の引数を記憶しておく必要 がある。ここでこの配列を $\psi_{t}(j)$ に記憶するとすると, $\psi_{t}(j)$ は (7) 式で表すことができる。

$$
\psi_{t+1}(j)=\underset{i}{\operatorname{argmax}}\left[\delta_{t}(i) a_{i j}\right]
$$

$\langle\mathbf{2} \cdot \mathbf{4}\rangle$ 学 習 問題 $(3)$ は, 与えられた学習用の 観測系列 $O$ に対して, (2) 式で与えられる $P(O \mid \lambda)$ を最大に する $\lambda$ を求めることである。つまり，

$$
\lambda_{\max }=\underset{\lambda}{\operatorname{argmax}} P(O \mid \lambda)
$$

と定式化することができる。(8) 式の最大化問題を解析的に 直接求める方法は知られていない。しかしながら, 次に示 す Baum-Welchアルゴリズム（EMアルゴリズム ${ }^{(16)}$ として も知られている）のような繰り返し法により, 尤度 $P(O \mid \lambda)$ が局所的に最大になるパラメータ $\lambda$ を求めることができる。

パラメータと観測系列が与えられたとき，時刻 $t$ で状態 $s_{i}$ から状態 $s_{j}$ への遷移が生じた確率 $\xi_{t}(i, j)$ を考えると, $\xi_{t}(i, j)$ は次式のように書くことができる。

$$
\xi_{t}(i, j)=\frac{\alpha_{t}(i) a_{i j} b_{j}\left(o_{t+1}\right) \beta_{t+1}(j)}{\sum_{i=1}^{N} \alpha_{T}(i)}
$$

いま $\gamma_{t}(i)$ を

$$
\gamma_{t}(i)=\sum_{j=1}^{N} \xi_{t}(i, j)
$$

と定義する。ここで $\gamma_{t}(i)$ は時刻 $t$ で状態 $i$ に存在する確率 である。 $\xi_{t}(i, j)$ と $\gamma_{t}(i)$ を用いることで, パラメータ $(\pi, a$, b) の学習は, 次式により再帰的に行うことができる。

$$
\begin{gathered}
\bar{\pi}_{i}=\gamma_{1}(i) \cdots \cdots \cdots \\
\bar{a}_{i j}=\frac{\sum_{t=1}^{T-1} \xi_{t}(i, j)}{\sum_{t=1}^{T-1} \gamma_{t}(i)} \cdots \cdots \\
\bar{b}_{j}(k)=\frac{\sum_{t: o_{t}=k}^{T} \gamma_{t}(j)}{\sum_{t=1}^{T} \gamma_{t}(j)}
\end{gathered}
$$

\section{3. ベクトル量子化}

HMM では, 通常, 時系列デー夕をそのまま用いるので はなく, 時系列デー夕を離散的なシンボル時系列に変換し たものを用いる。このため，まずはじめに，観測された時 系列データをシンボル時系列に変換する前処理が必要とな る。これはべクトル量子化と呼ばれる処理によって行われ る。このベクトル量子化は， $N$ 次元ベクトル $x$ を，あらか じめ用意しておいた代表パターン $C\left(=\left\{c_{i}\right\}\right)$ のうち一番 近いもので置き換える。ここで， $C$ をコードブック,$c_{i}$ を コードベクトルあるいはコードワードと呼ぶ。 $x$ をベクト ル量子化したコード $n$ は, $d(y, z)$ を $y$ と $z$ の距離を表す関 数とするとき，

$$
n=\underset{i}{\operatorname{argmin}} d\left(x, c_{i}\right)
$$

によって求められる。

同じ条件下で測定されたデータであっても，ノイズ等を 含めた確率的な変動により, 形状はさまざまである。そこ で，これら時系列データをシンボル系列として表すと，そ れらのシンボル列の間には, ある程度の類似性を含めるこ とができる。HMMによるパターン認識では，この類似性 を HMM で表現することになる。

時系列データをシンボル時系列に変換する方法について 説明する。はじめに, 事前に準備した学習用時系列データ を対象として特徴量（認識したい物理量）を抽出する。次 に, 図 2 に示すように, 抽出した特徴量に対してべクトル 量子化を行い，コードブックを作成する。以降は HMM で 取り扱う特徵量に対して, コードブックを用いてシンボル 時系列に変換する。認識時には, HMMで取り扱う特徵量 のデータに対して, 図 3 に示すように，コードブックを用 いてシンボル時系列に変換する。 


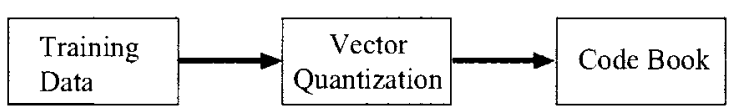

図 2 コードブックの作成

Fig. 2. Generation of Code Book.

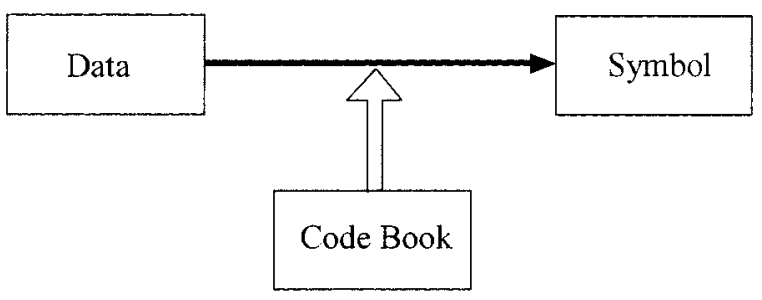

図 3 データのシンボル化

Fig. 3. Symbolization of data.

\section{4. 固定子巻線の短絡再現}

〈4・1〉 短絡再現実験 電動機において固定子卷線で の故障発生頻度は高い。文献 (8) によると, それは故障割 合の上位を占めていることが分かる。このため，電動機で の固定子巻線の状態を診断する技術の確立は，産業界にお いて重要な検討課題である。本論文では, 固定子巻線の故 障として，コイルの巻線間短絡に注目する。

コイルの巻線間短絡は, 電動機の巻線構造やコイル数等 により，実に多種多様のケースが考えられる。そして，これ らの短絡下での電動機の動作状況を確認するためには，さ まざまな短絡状態にある電動機を実際にいくつも準備する 必要がある。しかしながら, 長時間稼働により発生した短 絡を有する電動機を多数集めることは, 実際問題, 時間的, 経済的な面で負担が大きい。このことから，本論文では，新 品の電動機を用いて巻線間短絡を人為的に再現させる。

再現実験には, 定格出力 $2.2 \mathrm{~kW}$, 定格電圧 $200 \mathrm{~V}$, 定格電 流 $8.6 \mathrm{~A}, 4$ 極三相誘導電動機を用いる。この誘導機の固定 子のスロット数は 36 個, 卷線はダブル・スター結線であ り，1 スロットあたり 45 本のコイルが抻入されている。

本実験では，この誘導機 $\mathrm{W}$ 相の 1 スロットにおいて，1， 2，4，6 夕ーン分の四種類の巻線間短絡を発生させる。巻 線間短絡は，図 4 のように表すことができる。巻線間短絡 の再現は，2つのコイルに抒いてエナメル被覆をヤスリで 削ることで芯線を出し，その芯線部をハンダ接続する方法 で行う。

$\langle\mathbf{4} \cdot \mathbf{2}\rangle$ 測定結果 前述の各短絡状態下で誘導機に流れ る電流波形を測定する。誘導機は無負荷, 開ループ状態で回 転させる。同じ電源系統にインバー夕負荷等が接続され稼 働している場合には, 電源電圧が大きく変動することも考え られる。しかしながら, 今回の実験中には電圧変動がほとん どないことを確認した。誘導機の電流測定には, Tektronix 製の電流プローブ A6303 と同社製電流アンプ AM503B, 横 河電機製オシロスコープ DL1540Lを用いる。

誘導機が正常なときの $\mathrm{W}$ 相電流と，上記四種類の巻線間

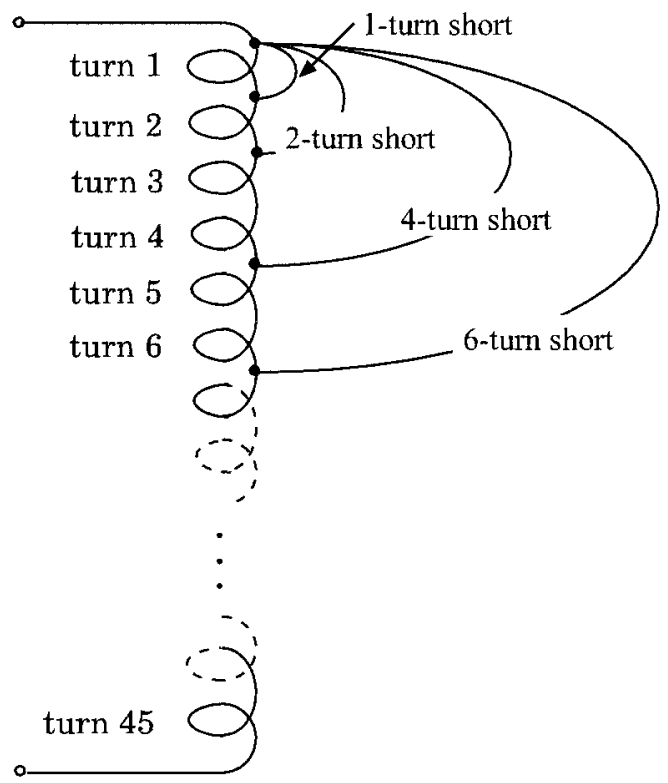

図 4 巻線間短絡故障

Fig. 4. Turn to turn short circuit faults.

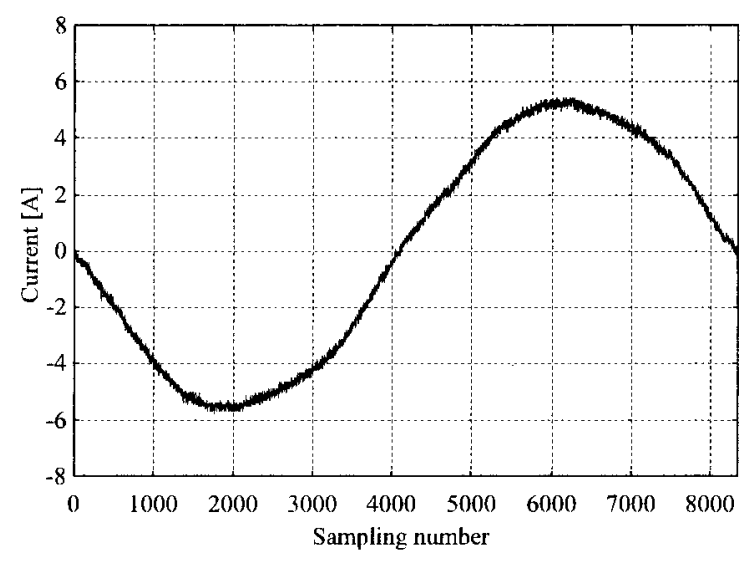

図 5 正常時の電流波形

Fig. 5. Current waveform in healthy mode.

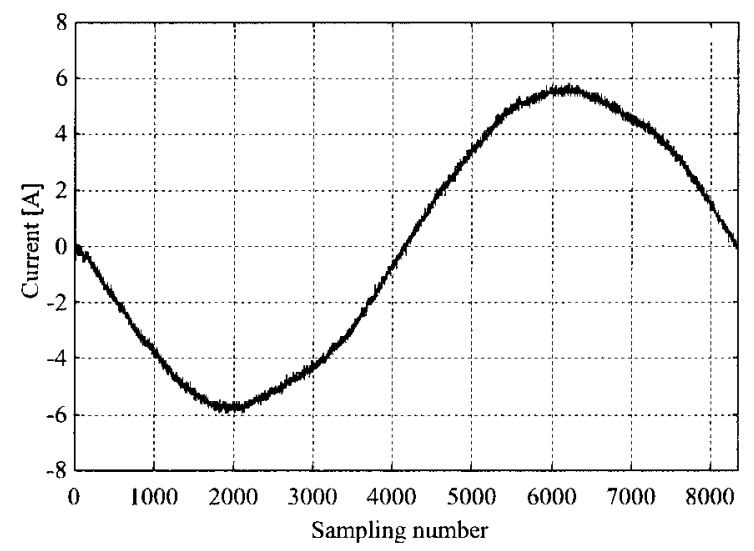

図 61 ターン分の短絡故障

Fig. 6. Current waveform in 1-turn short circuit fault. 
短絡時の $\mathrm{W}$ 相電流波形を図 5～図 9 に示す。図の縦軸は 電流值，横軸はサンプリング数を表している。今回，測定

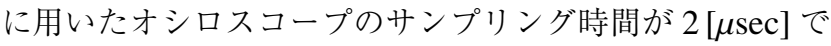
あることから，これらの図では，波形の一周期分に相当す る 8350 点を表示している。これらの波形群から，巻線間短 絡が発生し，その短絡したターン数が大きくなるにつれて，

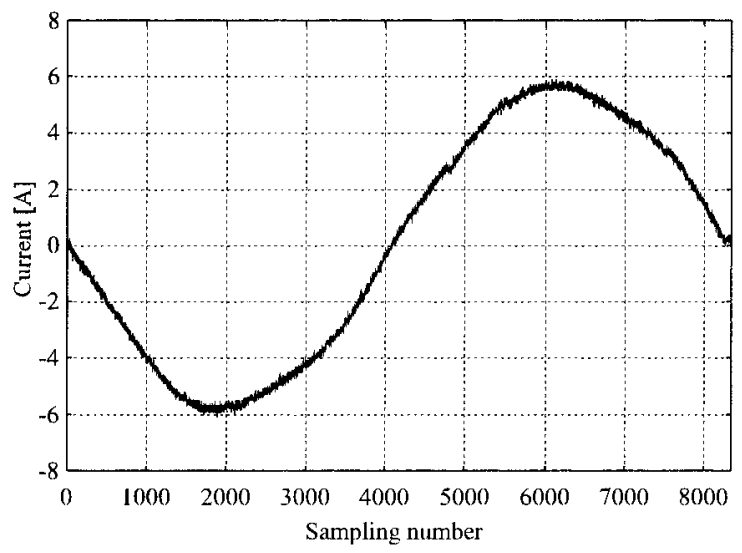

図 72 ターン分の短絡故障

Fig. 7. Current waveform in 2-turn short circuit fault.

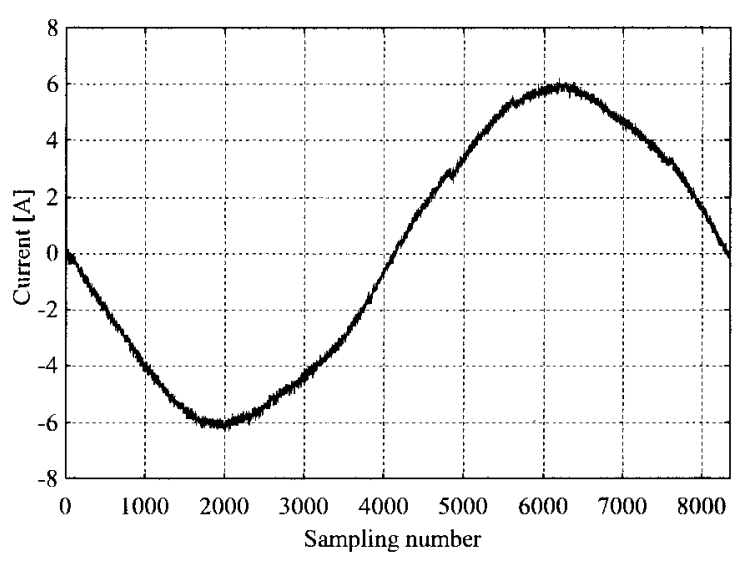

図 84 ターン分の短絡故障

Fig. 8. Current waveform in 4-turn short circuit fault.

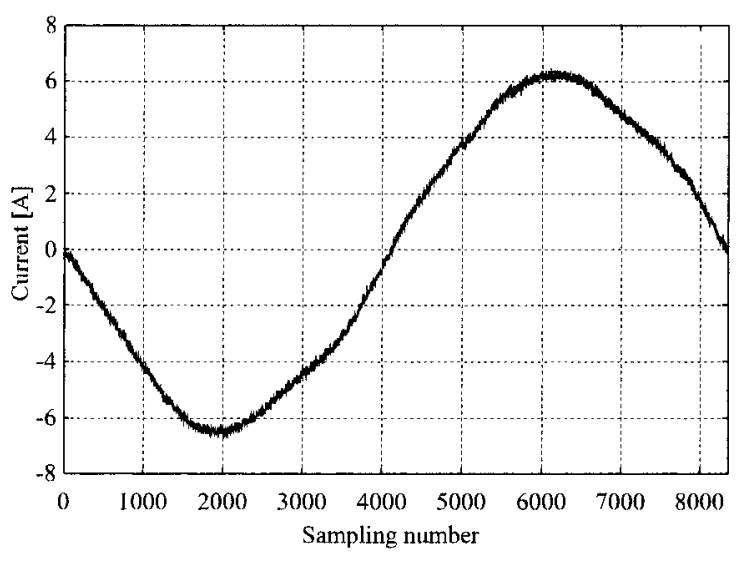

図 96 ターン分の短絡故障

Fig.9. Current waveform in 6-turn short circuit fault.
電流の波高值が変化しているだけでなく，波形形状そのも のも正常時に比べて大きく歪んでくることが分かる。この ことからも，波高值の情報のみを診断に用いるのではなく， 波形の歪みも含めた波形形状を情報源として診断に用いる ことで，高い判定能力を持つ診断システムを実現すること ができる。

\section{5. 短絡診断}

〈5・1〉 HMM に基づいた診断の概要 第 4 章で用い たものと同じ型式の誘導機を新たに 1 台用意して, $\mathrm{W}$ 相 において 6 ターン分の短絡を再現させる。ここでの短絡再 現は，第 4 章と同じ方法による。この 6 ターン分の短絡状 況下にある新たな誘導機から得られた $\mathrm{W}$ 相の電流波形を 図 10 に示す。本論文で提案する手法により，図 10 が予め 測定しておいた図 5〜図 9 までの五状態下のどの波形と最 も形状が近いかを判定することにより，固定子巻線の状態 の診断を行う。今回の診断では, 図 5～図 9 に示す波形か ら, それぞれ 10 点間隔ずつ值を抜き出して作る波形が, 元 の波形と比較しても形状の変化があまりないことから，一 周期サンプリング数を 835 点とデー夕数を削減した波形を 用いる。

音声認識で適用される HMM では, 音素等の直接観測す ることができない背後にある隠れた状態（=物理現象）を， 直接観測可能な信号を通して推定し，認識を行う。

一方, 巻線間短絡診断における隠れた状態について考え てみる。固定子巻線で巻線間短絡が発生した場合には，短 絡の程度によって固定子のインピーダンスが変化する。こ のインピーダンスの変化に伴い, 電動機内に生じる回転磁 界も変化してくる。回転磁界の变化は直接観測することは できないが，そのとき電動機に流れる電流は直接観測する ことができる。直接観測可能な電流から直接観測すること ができない回転磁界の変化の違いを, HMM で言うところ の隠れた状態と捉えてパターン認識を行い, 短絡診断する。

本診断手法の流れを図 11 に示す。はじめに, 電流波形 をべクトル量子化することによりシンボル系列に変換する。

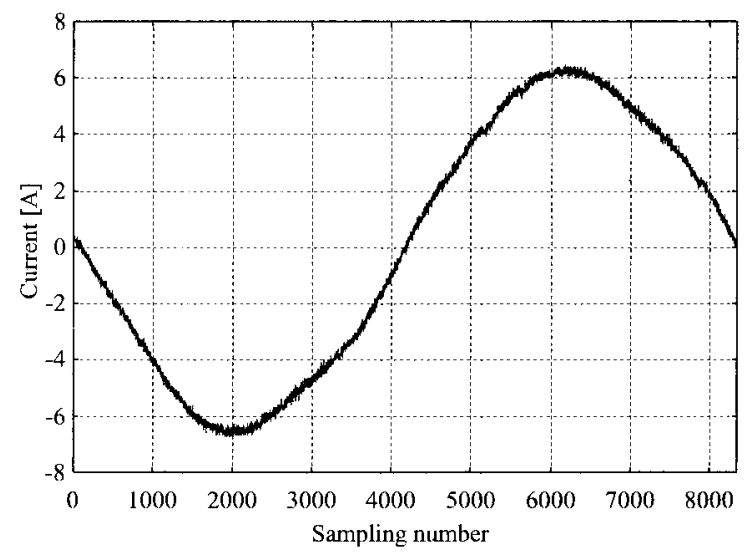

図 106 ターン分の短絡故障

Fig. 10. Current waveform in 6-turn short circuit fault. 


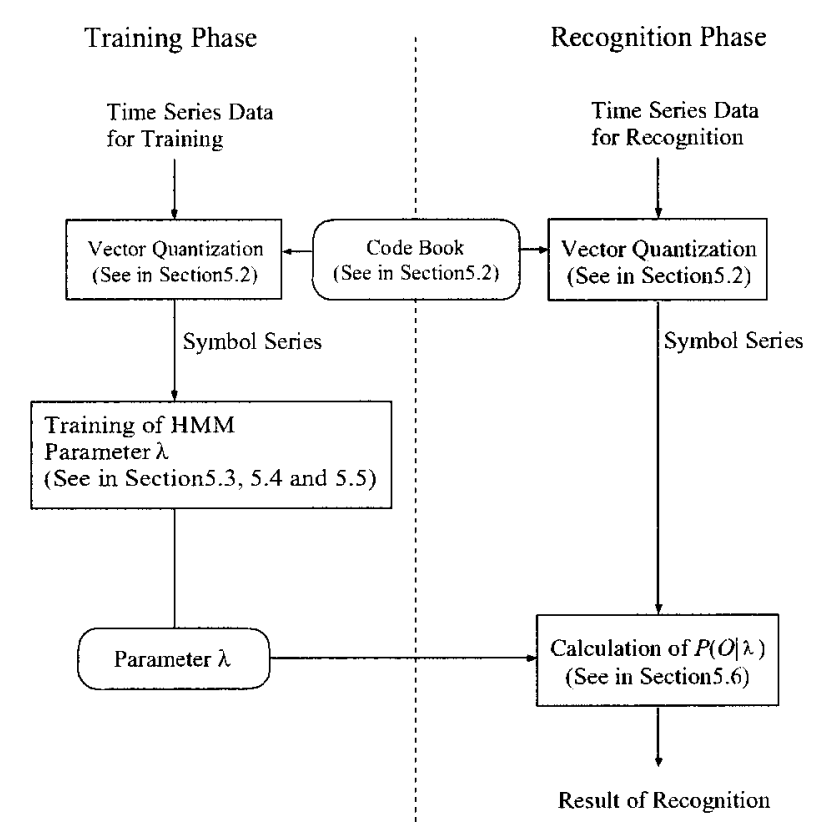

図 11 認識の流れ

Fig. 11. Flowchart of recognition.

次に，それらのシンボル系列に対する HMM パラメータの 学習を行う。これは第 2 章で示した HMM の 3 つの基本問 題の問題 (3) の解を用いて行う。さらに, 問題 $(2)$ の 解を用いて, 状態遷移系列を推定する。学習により各教師 データの HMM パラメータが最適化されると, 最後は未知 波形に対するパターン認識による評価である。認識には, 問題（1）の解を用いて，与えられた未知観測系列に対す る各波形のスコアを計算し，最も高いスコア，すなわち最 も尤度が高いときの波形を認識された結果とする。

〈5・2 $\rangle$ ベクトル量子化 電流波形に対するパターン認 識の前処理として，はじめにベクトル量子化を行う。この 作業により，学習させて㧤きたい波形パターン群からコード ブックを作成し，このコードブックをもとに，各電流波形の 時系列パターンをシンボル時系列に変換する。今回は, こ のコードベクトルを作成するためのベクトル量子化として, 自己組織化マップ (Self-Organizing-Maps : 以下 SOM) (17)(18) を適用する。SOM は，ランダムな出発点から教師なし学習 を経てパターン間の関係を表出することができ，ベクトル 量子化として適用することができる。

学習させて拉きたい波形群の電流值分布に対して SOM を適用することでコードブックを求める。今回用いる SOM は，標準的な増加学習型 SOM である。このとき求まった コードブックの要素, すなわちコードベクトルを表 1 に示 す。表 1 のコードベクトルの単位はアンペアである。また, 各コードベクトルに対応するシンボルを右側に示す。本論 文では, シンボルを自然数としており, シンボル数は 20 と 決定している。このコードブックをもとに, 測定された電 流值を，最も近い值のコードベクトルに対応したシンボル に置き換えることで，時系列データをシンボル時系列に変
表 1 コードベクトルとシンボルの対応関係

Table 1. Relation between code vectors and symbols.

\begin{tabular}{|c|c|}
\hline Code vector & Symbol \\
\hline \hline-5.73 & 1 \\
\hline-5.48 & 2 \\
\hline-4.96 & 3 \\
\hline-4.43 & 4 \\
\hline-3.81 & 5 \\
\hline-3.16 & 6 \\
\hline-2.44 & 7 \\
\hline-1.70 & 8 \\
\hline-0.94 & 9 \\
\hline-0.20 & 10 \\
\hline 0.50 & 11 \\
\hline 1.26 & 12 \\
\hline 2.03 & 13 \\
\hline 2.70 & 14 \\
\hline 3.34 & 15 \\
\hline 3.93 & 16 \\
\hline 4.49 & 17 \\
\hline 4.89 & 18 \\
\hline 5.39 & 19 \\
\hline 5.61 & 20 \\
\hline & \\
\hline
\end{tabular}

換する。

〈5・3〉 学 習 HMMによるパターンの学習を行 う。この学習段階では，〈5·2〉節で述べたべクトル量子化 により得られたシンボル時系列を用いて，記憶させる各波 形パターンの HMM パラメータを学習・生成する。一般の HMM では，任意の状態間での遷移が許される。しかしな がら，因果性を表現する電流波形パターンのような時系列 データのモデル化に打いては, 状態を横一列に並べたとき に左方向への遷移がない，すなわち時間が逆戻りしないモ デル “left-to-right 型モデル”が用いられる。今回の電流波 形のパターン認識では，この left-to-right 型モデルを採用 する。

HMM の状態数とシンボル数を決定すると, 電流波形パ ターンのシンボル時系列を状態数で分割する。そして, 各 状態 $s_{i}$ においてシンボル $x$ (ここでは $x$ は 1 から 20 まで の自然数）が出力される確率 $b_{i}(x)$ と, どのような確率で状 態が遷移していくかの状態遷移確率 $a_{i j}$ の計算を, その波 形パターンの尤度が極大となるように, Baum-Welchアル ゴリズムを用いて計算する。この計算によって求まった状 態遷移確率 $a_{i j}$ と出力確率 $b_{i}(x)$, 初期状態確率 $\pi_{i}$ を, 電流 波形パターンの HMM パラメータとしてコンピュータに記 憶させる。この処理を記憶させておきたいすべての波形に 対して行う。

〈5・4〉 状態数の決定 HMMによる学習では, HMM の状態数の決定は重要である。HMM の尤度計算において, 前向きアルゴリズムや後向きアルゴリズムをこのままコン ピュータで実行すると, $\alpha_{t}(i)$ や $\beta_{t}(i)$ などの值がアンダーフ ローを起こすことが多い。このアンダーフローを回避する ために, HMM の確率計算は，一般的に対数を用いて行わ れる。巻線正常時の電流波形を用いたときの HMM の状態 


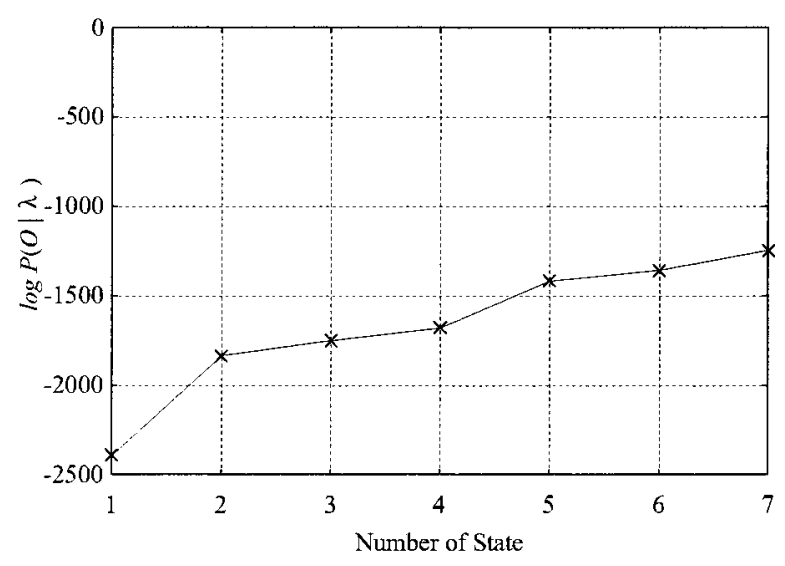

図 12 状態数と対数尤度の関係（正常時）

Fig. 12. Relation between numbers of state and log likelihood (healthy).

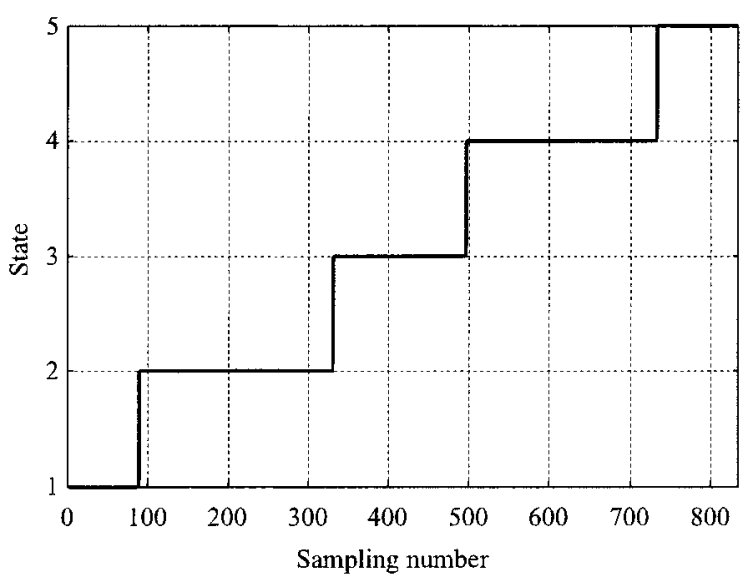

図 13 推定された状態遷移系列（正常時）

Fig. 13. Estimated state transition series (healthy).

数と尤度との関係を図 12 に示す。尤度は対数尤度として 表示する。図 12 より, 状態数を増加させると認識率は向 上することが分かる。しかしながら, 状態数の増加にとも ない，コンピュータ上での計算量が増加してしまう。つま り，HMM の認識率と計算量はトレードオフの関係にある。 今回の診断では，図 12 の結果をもとに, 認識率と計算量を 考慮して, HMM の状態数を 5 と決定する。

〈5.5〉 状態遷移系列の推定 状態が実際にどのよう に遷移していくかの状態遷移系列を正確に知ることはで きない。しかしながら, 学習によって求まったパラメータ と〈2・3〉節で説明した Viterbi アルゴリズムを用いること で, 最も尤もらしい状態の遷移系列を推定することができ る。本節では, Viterbiアルゴリズムに従って, 状態遷移系 列を推定する。ここで推定する対象波形として, 巻線正常 時の電流波形を用いる。

このとき推定された状態遷移系列の結果を図 13 に示す。 図 13 の横軸はサンプリング数, 縦軸は状態を表している。 $\langle 5 \cdot 1\rangle$ 節でも述べたように，今回の診断では，測定した各

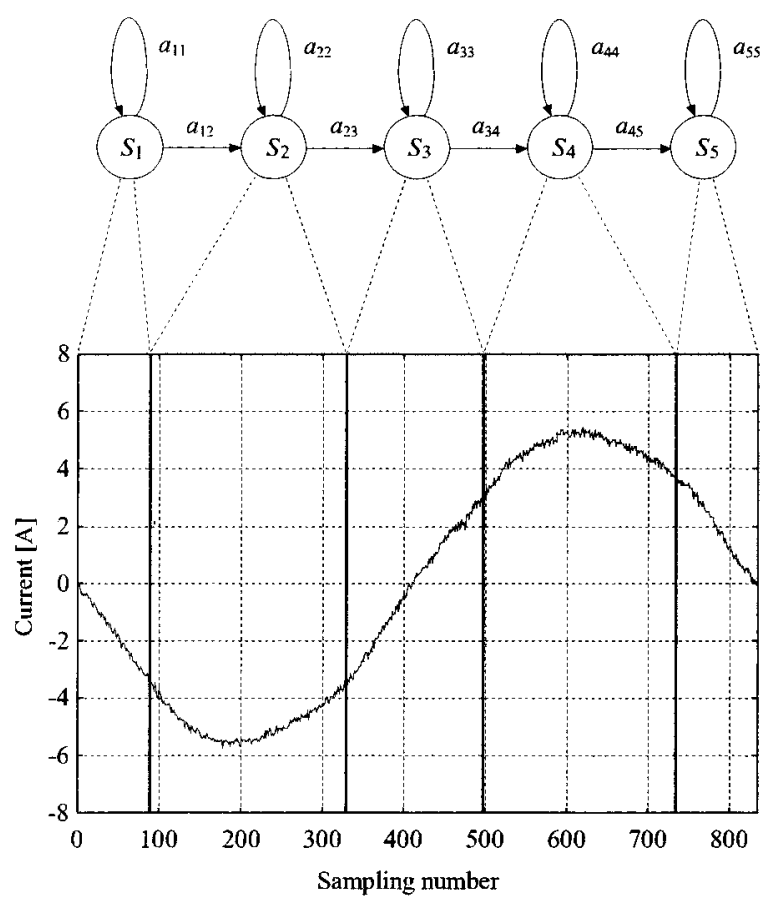

図 14 推定した状態遷移と電流波形との対応 (正常時)

Fig. 14. Relation between estimated state transition and current waveform (healthy).

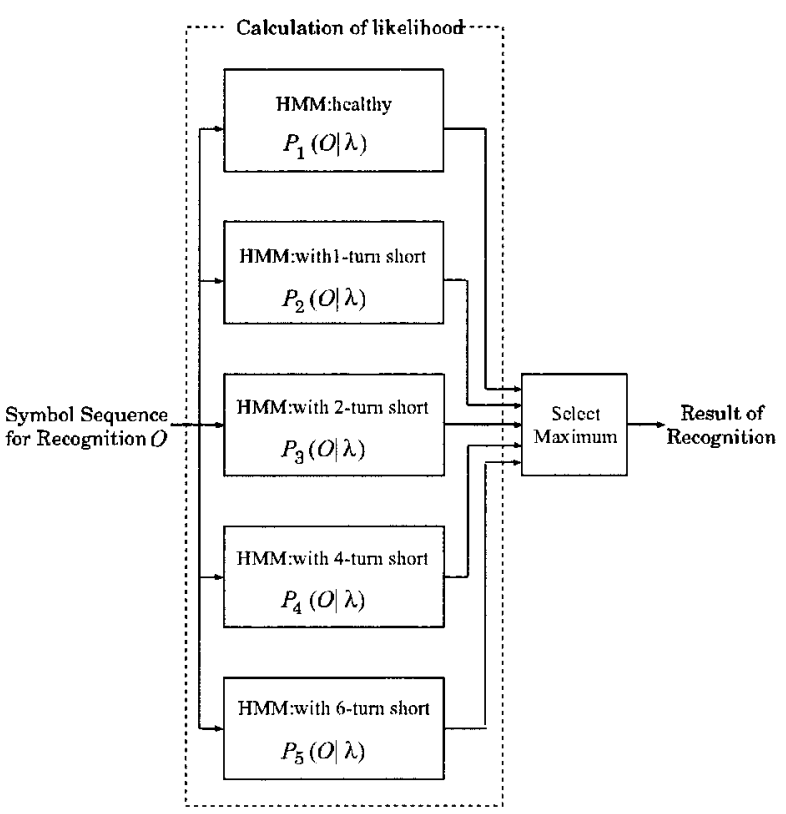

図 15 HMM による認識

Fig. 15. Recognition of HMM.

状態下での電流波形から 10 点間隔ずつの值を抜き出した 波形を用いているため，一周期サンプリング数は 835 点で ある。図 13 では, 状態は状態 1 から時間経過とともに徐々 に遷移して, 最終的に状態 5 へ变化していく様子が分かる。 また，図 13 より，推定した状態遷移と図 5 に示す正常時 


\section{表 2 認識結果}

Table 2. Result of recognition.

\begin{tabular}{|c||c|}
\hline $\begin{array}{c}\log \text { likelihood } \\
\log P_{i}(O \mid \lambda)\end{array}$ & Value \\
\hline \hline $\log P_{1}(O \mid \lambda)$ & -3128 \\
\hline $\log P_{2}(O \mid \lambda)$ & -1642 \\
\hline $\log P_{3}(O \mid \lambda)$ & -1533 \\
\hline $\log P_{4}(O \mid \lambda)$ & -1497 \\
\hline $\log P_{5}(O \mid \lambda)$ & -1485 \\
\hline
\end{tabular}

電流波形との対応関係は，図 14 のように図示することが できる。ただし図 14 に示す電流波形も，サンプリング数 は図 5 から 10 点間隔ずつの值を抜き出した 835 点である。

$\langle\mathbf{5 \cdot 6 \rangle}$ 認識結果 認識時には, 認識対象とする波形パ ターンの時系列データに対して，〈5·2〉節で作成したコー ドブックをもとに，シンボル時系列への変換を行う。そし て図 15 に示すように, 学習段階で生成され, コンピュータ に記憶されている各状態下での HMM パラメータと，認識 対象パターンのシンボル時系列を用いることにより，認識 対象パターンの尤度 $P_{i}(O \mid \lambda)$ (今回は, $\left.i=1,2, \cdots, 5\right)$ を計 算する。そして，尤度が最大となるときが，現在の固定子 巻線の状態であると診断する。本論文で用いた HMMによ る学習から状態遷移系列推定, 評価までの一連の診断プロ グラムは，C言語によって記述され，Linux 上で動作する。 新たな誘導機から得られた 6 ターン分短絡時の電流波形 （図 10 に相当）に対する認識結果を表 2 に示す。この診断 の結果, 6 ターン分短絡時の尤度 $P_{5}(O \mid \lambda)$ が最も高くなり, 正しく巻線状態を判別することができた。また，その他の 巻線間短絡に対しても同様な診断を行ったところ, 正しく 認識できていることが確認できた。

今回の短絡実験では, 数十ターン以上短絡させた誘導機 も用意した。この誘導機に流れる電流波形を測定したとこ ろ，波高值や歪みはさらに大きくなり，正常時の波形から は，かけ離れたものとなった。そのため，これら大きな短 絡に対しては，波高值のみに注目することで，短絡発生を 見分けることができる。しかしながら，何ターン分のコイ ルが短絡したのかを特定する場合には，波形の形状を考慮 して診断する本手法は有用である。

\section{6. むすび}

本論文では, 電動機の中で故障発生頻度の高い固定子巻線 の短絡に対して, 動的な信号の表現能力に優れている HMM を用いて診断する手法を提案した。さらに，実際の三相誘 導電動機において短絡故障を人為的に再現させ，それらの データを用いて波形のパターン認識を行った。その結果， 短絡が発生しているか否か，および何ターン分の短絡が発 生しているかの状態を正しく診断できることができた。今 後は，引き続き，さまざまな短絡故障を再現させ，その状 態下での電流波形を用いて認識を行う予定である。

今回の短絡実験は，電源の電圧变動がほとんどない状態
で実施した。しかし実際の現場では，さまざまな負荷が系 統に接続されており, 電源電圧が大きく変動することも考 えられる。このような場合の診断に関しては今後の課題と する。

また，電動機での故障は単独でなく，複合して起こる場 合も考えられる。しかしながら，これらの故障の検出なら びに故障部位の特定といった診断までを電流波形の形状だ けから判定することは容易でない可能性もある。このこと から, 固定子巻線の短絡だけでなく機械的な故障も含めた 電動機で起こりうるさまざまな故障の故障の解析や, 故障 検出ならびに診断の検討も, 今後の課題として取り組む予 定である。

(平成 17 年 2 月 17 日受付，平成 17 年 10 月 21 日再受付)

\section{文献}

(1) R.R. Schoen, T.G. Habetler, F. Kamran, and R.G. Bartheld: "Motor Bearing Damage Detection Using Stator Current Monitoring", IEEE Trans. Industr. Applic., Vol.31, No.6, pp.1274-1279 (1995)

(2) R.R. Schoen, B.K. Lin, T.G. Habetler, J.H. Schlag, and S. Farag: "An Unsupervised, On-Line System for Induction Motor Fault Detection Using Stator Current Monitoring”, IEEE Trans. Industr. Applic., Vol.31, No.6, pp.12801286 (1995)

(3) M.A. Cash, T.G. Habetler, and G.B. Kliman: "Insulation Failure Prediction in AC Machines Using Line-Neural Voltages", IEEE Trans. Industr. Applic., Vol.34, No.6, pp.1234-1239 (1998)

(4) M.E.H. Benbouzid, M. Vieira, and C. Theys: "Induction Motors' Faults Detection and Localization Using Stator Current Advanced Signal Processing Techniques", IEEE Trans. Power Electronics, Vol.14, No.1, pp.14-22 (1999)

(5) B. Li, M.-Y. Chow, Y. Tipsuwan, and J.C. Hung: "Neural-Network-Based Motor Rolling Bearing Fault Diagnosis", IEEE Trans. on Industr. Applic., Vol.47, No.5, pp.1060-1069 (2000)

(6) S.B. Lee, R.M. Tallam, and T.G. Habetler: "A Robust, On-Line Turn-Fault Detection Technique for Induction Machines Based on Monitoring the Sequence Component Impedance Matrix”, IEEE Trans. Power Electronics, Vol.18, No.3, pp.865-872 (2003)

(7) H. Douglas, P. Pillay, and A.K. Ziarani: "A New Algorithm for Transient Motor Current Signature Analysis Using Wavelets", IEEE Trans. Industr. Applic., Vol.40, No.5, pp.1361-1368 (2004)

(8) O.V. Thorsen and M. Dalva: "Failure Identification and Analysis for HighVoltage Induction", IEEE Trans. Industr. Applic., Vol.35, No.4, pp.810-818 (1999)

（9）河村達雄 ・田中祀捷：電気設備の診断技術, 電気学会 (2003)

(10) J.A. Haylock, B.C. Mecrow, A.G. Jack, and D.J. Athkinson: "Operation of Fault Tolerant Machines With Winding Failure", IEEE Trans. Energy Conversion, Vol.14, No.4, pp.1490-1495 (1999)

(11) S.M.A. Cruz and A.J.M. Cardoso: "Stator Winding Fault Diagnosis in Three-Phase Synchronous and Asynchronous Motors, by the Extended Park's Vector Approach", IEEE Trans. Industr. Applic., Vol.37, No.5, pp.1227-1233 (2001)

(12) J.S. Hsu: "Monitoring of Defects in Induction Motors Through Air-Gap Torque Observation", IEEE Trans. Industr. Applic., Vol.31, No.5, pp.10161021 (1995)

(13) X.D. Huang, Y. Ariki, and M.A. Jack: Hidden Markov Model for Speech Recognition, Edinburgh University Press (1990)

(14) L.R. Rabiner and B. Juang: Fundamentals of Speech Recognition, PrenticeHall (1993)

(15) L.R. Rabiner: "A Tutorial on Hidden Markov Models and Selected Applications in Speech Recognition", Proc. IEEE, Vo.77, No.2, pp.257-285 (1989)

(16) G. McLachlan and T. Krishnan: The EM Algorithm and Extensions, Wiley (1997)

(17) T. Kohonen: "The self-organizing map", Proc. IEEE, Vol.78, No.9, pp.1464-1480 (1990)

(18) T. Kohonen: "Self-Organizing Maps", Springer Series in Information Sciences, Vol.30 (2001) 
中 村 久栄 (正員) 1971 年 7 月 28 日生。1 997 年 3 月名古

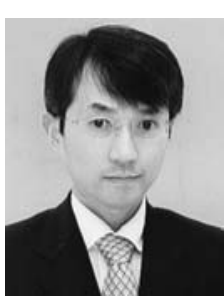

屋工業大学大学院工学研究科博士前期課程電気情 報工学専攻修了。2002 年 3 月名古屋大学大学院 工学研究科博士後期課程電気工学専攻単位取得退 学。同年 4 月株式会社トーエネック入社。現在に 至る。1997 年 4 月〜1999 年 3 月ファナック株式 会社勤務。主として, 電気機器の制御, 故障·劣 化診断に関する研究開発に従事。博士 (工学)。計 測自動制御学会, システム制御情報学会, 情報処理学会, 電気設備学 会, IEEE 各会員。

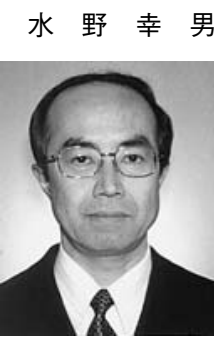

（正員） 1958 年 7 月 8 日生。 1986 年 3 月名古屋 大学大学院工学研究科博士後期課程電気工学.電 気工学第二および電子工学専攻修了。同年 4 月豊 橋技術科学大学電気・電子工学系助手。1993 年 11 月名古屋工業大学電気情報工学科助教授。2003 年 1 月同教授。現在，同大学大学院ながれ領域機 能工学専攻教授。主として, 極低温電気絶縁, 外 部絶縁，絶縁劣化診断，商用周波電界·磁界の定 量化に関する研究に従事。工学博士。低温工学会, IEEE 各会員。
鈴 木 達 也 (正員) 1964 年 1 月 3 日生。1991 年 3 月名古屋

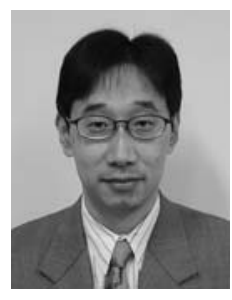
大学大学院工学研究科博士後期課程電子機械工学 専攻修了。工学博士。同年 4 月名古屋大学工学部 助手。2006 年 4 月同教授。現在に至る。この間, 1998 年から 1 年間, U.C.Berkeley 客員研究員。知 的なモーションコントロール，ハイブリッドシス テム論に基づく知的システム構築とその実システ ムへの応用に関する研究に従事。1995 年電気学 会論文賞, 2004 年 SICE システム情報部門学術講演会論文賞などを受 賞。電子情報通信学会, 計測自動制御学会, システム制御情報学会, 日本ロボット学会, 日本機械学会, 人間工学会, IEEE 各会員。 